\title{
Podsumowanie Kongresu ESMO 2014
}

W tegorocznym Kongresie European Society for Medical Oncology (ESMO) wzięła udział rekordowa liczba 19809 uczestników; delegaci reprezentowali 134 kraje. W czasie trwających 5 dni obrad odbyło się 180 sesji, podczas których 460 lektorów wygłosiło wykłady. W niniejszym podsumowaniu zawarto wybrane informacje na temat doniesień przedstawionych w ramach specjalnych sesji prezydenckich (Presidential Sessions) — dwie z nich odbyły się w czasie trwania Kongresu.

W czasie 1. sesji prezydenckiej przedstawiono wyniki dotyczące ostatecznej analizy czasu przeżycia całkowitego (overall survival - OS) 808 chorych na przerzutowego HER2-dodatniego raka piersi, które leczono w ramach badania CLEOPATRA. W badaniu stosowano pertuzumab/placebo z trastuzumabem i docetakselem. Wcześniej opublikowano wyniki świadczące o dłuższym czasie bez progresji choroby (progression-free survival — PFS), który w ramieniu z pertuzumabem wyniósł 18,5 miesiąca w porównaniu z 12,4 miesiąca w ramieniu kontrolnym (hazard względny $[\mathrm{HR}]=0,62$, $\mathrm{p}<0,001)$. Mediana OS w grupie eksperymentalnej wyniosła 56,5 miesiąca i była o 15,7 miesiąca dłuższa w porównaniu $\mathrm{z}$ ramieniem kontrolnym $(\mathrm{HR}=0,68, \mathrm{p}=0,0002)$. Wyniki te skłoniły ekspertów komentujących prezentowane wyniki do uznania trójlekowego schematu (pertuzumab + trastuzumab + docetaksel) za nowy standard postępowania u chorych w 1. linii przerzutowego HER2-dodatniego raka piersi.

W tej samej sesji przedstawiono wyniki badania MAGRIT, w którym oceniano przydatność szczepionki MAGE-A3 u chorych po radykalnej operacji wykonanej z powodu niedrobnokomórkowego raka płuca (wyłącznie raki płuca z ekspresją MAGE-A3, stopień IB, II, IIIA [TNM, v. 6], +/- uzupełniająca chemioterapia). Łącznie 2272 uczestników badania poddano terapii MAGE-A3 Cl lub placebo przez 27 miesięcy. Wyniki badania nie pozwoliły na zaobserwowanie poprawy pod względem czasu przeżycia bez objawów choroby (disease free survival - DFS) w związku ze stosowaniem MAGE-A3 Cl zarówno w całkowitej grupie chorych, jak i w grupie, w której nie stosowano uzupełniającej chemioterapii.

W czasie 1. sesji prezydenckiej przedstawiono również wyniki badania IMPRESS, obejmującego także chorych na niedrobnokomórkowego raka płuca z mutacją genu EGFR, u których po leczeniu pierwszej linii z użyciem gefitynibu dochodziło do progresji choroby. Randomizacji poddano 265 chorych, losowo przydzielając ich do grupy: 1) gefitynib $250 \mathrm{mg} / \mathrm{d}$ z cisplatyną $\left(75 \mathrm{mg} / \mathrm{m}^{2}\right) /$ pemetreksedem $\left(500 \mathrm{mg} / \mathrm{m}^{2}\right)$ lub placebo z cisplatyną $\left(75 \mathrm{mg} / \mathrm{m}^{2}\right) /$ pemetreksedem $\left(500 \mathrm{mg} / \mathrm{m}^{2}\right)$. Nie zaobserwowano różnic pod względem PFS. Autorzy stwierdzili, że w przypadku progresji po leczeniu z użyciem gefinitybu należy stosować wyłącznie chemioterapię dwulekową.

Podczas 2. sesji prezydenckiej przedstawiono wyniki dotyczące 370 chorych na zaawansowanego czerniaka, u których stwierdzono progresję podczas, lub po zakończeniu terapii anty-CTLA4 $\mathrm{i}$ inhibitorem BRAF w przypadku mutacji tego genu (BRAF V600), włączonych do badania III fazy ChecMate-037 z randomizacją. Stosowano niwolumab (przeciwciało monoklonalne skierowane przeciw PD-1) lub chemioterapię (dakarbazynę lub karboplatynę z paklitakselem). Zaprezentowane wyniki nowej terapii są bardzo obiecujące. Odsetek odpowiedzi całkowitych (overall response rate - ORR) wyniósł $32 \%$ w grupie eksperymentalnej w porównaniu z $11 \%$ w grupie poddanej chemioterapii. W grupie leczonej niwolumabem nie osiągnięto jeszcze mediany czasu odpowiedzi (95\% chorych nadal poddawanych terapii), która w ramieniu kontrolnym wyniosła 3,6 miesiąca. Lepszą odpowiedź na nową terapię osiągnięto niezależnie od obecności ekspresji PD-L1, stanu mutacji BRAF oraz korzyści z wcześniejszego leczenia anty-CTLA4.

W tej samej sesji przedstawiono także rezultaty badania III fazy COMBI-v, obejmującego 704 chorych na przerzutowego czerniaka z mutacją BRAF V600E/K, u których $w 1$. linii leczenia stosowano dabrafenib $z$ trametynibem lub wemurafenib w monoterapii. Wyniki analizy okresowej były na tyle istotne, że zgodnie z protokołem uznano je za końcowe. Mediana PFS u chorych poddanych terapii dabrafenibem $z$ trametynibem była dłuższa o 4 miesiące (11,4 mies. vs 7,3 mies., HR =0,56, $p<0,001)$, korzyść odnotowano również $w$ zakresie OS (mediana OS u chorych stosujących wemurafenib wyniosła 17,2 mies., nie osiągnięto jej u chorych w ramieniu terapii skojarzonej, $\mathrm{HR}=0,69$, $p=0,002)$. Toksyczność była podobna w obu grupach. Wyniki te stwarzają podstawę do uznania terapii złożonej z inhibitorów BRAF i MEK w przyszłości za standard leczenia chorych na przerzutowego czerniaka. Bezpośrednio 
po wynikach badania COMBI-v zaprezentowano podobne badanie III fazy (coBRIM), w których określono skuteczność dołączenia cobimetynibu (inhibitora MEK) do wemurafenibu (czyli inhibitora BRAF) u dotychczas nieleczonych chorych na nieoperacyjnego, miejscowo zaawansowanego lub przerzutowego czerniaka z mutacją BRAFV600. Do badania włączono 495 chorych. Terapia dwulekowa była bardziej skuteczna zarówno pod względem PFS (11,3 mies. vs 6,0 mies., $\mathrm{HR}=0,60, \mathrm{p}<0,0003$ ), jak i OS (odsetki 9-miesięcznego OS wyniosły odpowiednio $81,1 \%$ i 72,5\%, HR=0,65, $\mathrm{p}=0,046$ ). Działania niepożądane częściej wystąpiły w grupie poddanej terapii dwulekowej. Wyniki tego badania, podobnie jak poprzednio omówionego badania COMBI-v, wskazują na istotną korzyść z jednoczesnej terapii inhibitorami BRAF i MEK u chorych na czerniaka z mutacją BRAF V600.

Ponadto w subiektywnej ocenie autorów spośród badań prezentowanych poza sesjami prezydenckimi warto przywołać badania LUX-Lung 8 oraz COU-AA-302. W badaniu LUX-Lung 8 udział wzięli chorzy na nabłonkowego raka płuca, u których doszło do progresji po leczeniu obejmującym przynajmniej 4 kursy chemioterapii opartej na związkach platyny. W ramach badania porównano skuteczność afatynibu z erlotynibem. Do badania włączono 795 chorych (85\% stanowili mężczyźni, 5\% chorych nigdy nie paliło papierosów). Wyniki były znamiennie lepsze w ramieniu z afatynibem (mediana PFS wyniosła 2,4 mies. vs 1,9 mies. w ramieniu z erlotynibem, $p=0,0427$; odsetek kontroli choroby [disease control rate - DCR] wyniósł odpowiednio 45,7\% i 36,8\%, p =0,020), niemniej bezwzględna korzyść z terapii była niewielka przy porównywalnej toksyczności. W trakcie sesji dotyczącej wskazań do leczenia inhibitorami kinazy tyrozynowej EGRF stwierdzono, że u chorych na płaskonabłonkowego raka płuca należy stosować przede wszystkim chemioterapię, gdyż w tej grupie chorych rzadko stwierdza się u mutację aktywującą EGFR. Należy także wspomnieć wyniki badania COU-AA-302, w którym u 1088 chorych na rozsianego raka prostaty opornego na kastrację (mCRPC), bez wcześniejszej chemioterapii, stosowano prednizon +/abirateron. Podczas Kongresu przedstawiono ostateczne wyniki OS. Bezwzględna różnica w medianie OS wyniosła ponad 4 miesiące na korzyść terapii abirateronem $(34,7$ vs 30,3 mies., $\mathrm{HR}=0,80, \mathrm{p}=0,0027$ ).

\section{Dr n. med. Wojciech M. Wysocki}

Klinika Chirurgii Onkologicznej

Centrum Onkologii - Instytut, Oddział w Krakowie

ul. Garncarska 11, 31-114 Kraków

e-mail:z5wysock@cyf-kr.edu.pl

\section{Lek. Katarzyna Pogoda}

Klinika Nowotworów Piersi i Chirurgii Rekonstrukcyjnej

Centrum Onkologii - Instytut

ul. Roentgena 5, 02-781 Warszawa

e-mail: katarzynapogoda@coi.pl

Udział autorów w przygotowaniu sprawozdania był równorzędny. 